organs besides foliage are found, it being by no means absolutely certain that because the foliage is identical the species are so. The discussion raised by Prof. Haughton, and continued by Prof. Duncan and Mr. Wallace, seems therefore hardly worth prolonging, since it is based upon an assumption that is only probably correct. But even if the identity were proved, a single species is not satisfactory evidence of former temperature.

I am indebted to Mr. Winslow Jones for the only information that I have yet obtained about the growth of either species in England. He recollects a small tree of $A$. excelsa, growing near the water's edge in a garden on the upper portion of Falmouth Harbour, which he believes died three years ago. He has seen flourishing trees at Naples, Cintra, Malta, and Algiers, but even Northern Italy seems beyond the range of successful cultivation. Of the two A. Cunninghami seems the more tender, though possibly its le is symmetric growth may have excluded it from many gardens. In Madeira it grows generally best close to the sea and in sheltered places.

Lindley was mistaken in regarding the two species as one. All the needle-leaved (Eutacta) section of Araucaria are certainly closely allied, for the species, however distinct in other respects, possess two kinds of foliage, that of the young plants being identical in all : yet otherwise the species are clearly and distinctly marked off from each other.

With further regard to the identification of the Bournemouth foliage with Araucaria, I find that Massalongo ${ }^{1}$ gives an excellent photograph of the same foliage from Chiavon, in North Italy, and of an immature cone consisting of 250 scales. Although existing Sequoias have cones with from I6 to zo scales, Schimper says : "Il est sans aucun doute un Sequoia et peut-être identique au S. Sternbergii. Les cônes ont la plus grande ressemblance avec ceux du S. gigantea " (Pal. Végétale," vol. iii. p. 573). I am beginning to lose all faith in the so-called science of palæo-botany as worked out by our Teutonic brethren. Not only is the above quotation an absurdity, for which Heer is responsible, but I fail to see any good evidence to support the change made by Heer from Araucaria ${ }^{2}$ Siernbergii to Sequoia Sternbergii. The foliage is more Araucaria-like than Sequoia-like, and has been found associated with an Araucaria cone, but never with any Sequoia cones. It has nothing to do with the Icelandic foliage, neither with the Upper Miocene foliage from Turin, nor that from Bilin nor Oeningen. The true Araucaria Sternbergii characterises a wellnuarked horizon, that of the Newer Eocene or Oligocene in Central Europe, and has been found at Barton in Hampshire it differs from the Middle Eocene form ( $A$. venetus, Mass.) of England and Italy in the needle-like leaves hugging more closely to the branchlet, as the latter differs in its turn from the Araucaria of the Grès du Soissonnais, which has needles very widely opened out. This progressive change may have taken place pari passu with the changing climate. At Sheppey, where foliage is plentiful, I have met with a beautifully-preserved axis of an Araucaria cone with the basal scales attached, exactly as we find them in the existing species.

Now with regard to $\mathrm{Mr}$. Wallace's letter, I pointed out in NATURE, vol. xix. p. I26, that the Tertiary fossil plants, even of the Eocene, require at most an increase in temperature of $20^{\circ}$, and that the land connection between Europe, Greenland, and America, which there is reason to suppose existed then, would, by shutting out Arctic currents, have produced more than the required increment. If this theory appeared for the first time in my article, however clumsily I may have worded it, and if it has been of use to $\mathrm{Mr}$. Wallace, it is only fair that the fact should be acknowlsdged, while if it has escaped his notice he will perhaps pardon my now drawing his attention to it. At the same time the publication of the Tertiary flora of North-East Siberia, which I had not then seen, and of Saghalien, has modified the views I put forward in a manner which I trust I may shortly find time to explain.

J. Starkie Gardner

Chalk

Mr. WALLACE's theory that chalk was deposited in compara tively shallow water requires careful examination before it is accepted by geologists. I do not think he has given sufficient evidence to bear out his views which are necessary to his theory of continents.

Mr. Wallace cites the resemblance between chalk and Globigerina-ooze, namely -

The similarity of the minute organisms found to compose a

I "Specimen photographicum." Verona, 1859. Plate xxi.

2 Actually described as Araucarites, a useleas motification in this instance. considerable portion of both deposits ; several species of Globigerina appearing to be identical in the chalk and the modern Atlantic mud; the presence of Coccoliths and Discoliths in both formations; the abundance of Sponges in both; the presence of Porifera vitrea, the nearest representative of the Ventriculites of the white chalk; the resemblance of the forms of Echinoderms ; and without attempting to reconcile these with a shallow sea-deposit, he proceeds to state the case on the other side. This consists of the difference in analysis between chalk and Globigerina-ooze, the former containing more carbonate of lime and less alumina, the presence of silica in the Globi yerina-ooze being perhaps counterbalanced by the flints in the chalk. The greater proportion of alumina certainly points to different conditions, which $\mathrm{Mr}$. Wallace considers to be that chalk is the very fine mud produced by the disintegration of coral-reefs, and mentions a deposit resembling chalk at Oahu in the Sandwich Islands and the deposit in several growing reefs, without however attempting to show that there is any probability that the remains found in these would bear any resemblance to the Sponges and Echinoderms of the chalk, or why we find no remains of these Cretaceous coral-reefs.

$\mathrm{Mr}$. Wallace does not state in what the greater resemblance between chalk and Globigerina-ooze of shallow over deep water consists, but he looks on it as "weighty evidence."

Mr. Gwyn Jeffries, he says, finds all the Mollusca of the chalk to be shallow-water forms, many living at forty to fifty fathoms, some confined to still shallower waters, while deep-sea forms are absent. The late Dr. S. P. Woodward considered that Ammonites probably lived in water not over thirty fathoms; and these facts are as difficult to reconcile with Mr. Wallace's views that chalk was deposited in a sea of not over a few thousand feet as in a deeper sea.

The rareness of corals and absence of coralline beds of the age of the Lower or Upper Chalk is an important objection to the theory that chalk was deposited similarly to the Oahu chalk, the beds of Maestricht and Faxoe being above the chalk, and the former are not even conformable with it.

The point I think is still an open one, whether we shall accept Mr. Wallace's views that chalk was deposited in a comparatively shallow sea and not very far from land, or in a deep sea, the immense break between the chalk and Eocene beds giving ample time for very considerable alteration to have taken place in the disposition of land in the interval. I send this letter in the hope that a discussion on the point may elicit new facts bearing on the subject.

8, Inverness Terrace, Kensington Gardens, W.

\section{On Estimating the Height of Clouds by Photography and the Stereoscope}

THE great practical value of meteorological science and the desirability of extending its usefulness by the collection of data relating to atmospheric current will perhaps be sufficient excuse for asking attention to anything likely to promote this end.

In studying the currents and other peculiarities of the atmosphere a method of estimating the height, motion, and character, as also the position with respect to each other, of each stratum of cloud, is a requirement of almost paramount importance, the value of the means employed being proportional to the number of particulars provided in its record, and the facility with which any set of observations can be compared to another at any future period. With such ever-changing subjects as clouds in constant motion, and having no strongly-defined marks, the use of theodolites is almost out of the question, and the sextant and mirror process for similar reasons would be a very tedious operation

These considerations have induced me to endeavour to make use of photography and the stereoscope, the former to secure a couple of simultaneously-exposed photographs at the extremities of a base line, and the latter to observe them reproduced apparently solid for the respective distances of the points composing the picture to be measured when superimposed on a scale of distances and placed in it. The base line is thus practically reduced to the width of the eyes, and the difficulties arising from motion eliminated.

The recording apparatus consists of a base 50 or Ioo feet long, constructed of wood and turning on a pivot at the centre of its length, its extremities being suitably supported by a framework of wood or other material upon which they could easily roll. The small cameras for the ends of this are each to be hinged at the back of its base to a second board having a graduated quadrant and rackwork erected from one of its sides for adjusting 